International Journal of Agriculture, Environment and Bioresearch

Vol. 06, No. 06; 2021

ISSN: $2456-8643$

\title{
USE OF CYTOCHROMES P450 AND MIXED-FUNCTION OXIDASES (MFO) IN MYTILUS GALLOPROVINCIALIS AND PERNAPERNA AS BIOMARKERS OF POLLUTION IN AGADIR MARINE BAY (SOUTH OF MOROCCO)
}

\author{
Mohamad Abbassi ${ }^{1,2 *}$, Laila Aboudlou ${ }^{1}$, Maryem Nadir ${ }^{1}$, Samir Bari ${ }^{1}$, Hamza Zine ${ }^{3}$, Bah Hamoudi ${ }^{1,4}$, Imane \\ Charioui $^{1}$, Omar Achahour ${ }^{5}$, Abdellah Bouhaimi ${ }^{6}$, Abderrahmane Zekhnini ${ }^{6}$, Jean François Narbonne ${ }^{7}$ and \\ Abderrazak Kaaya ${ }^{{ }^{*}}$ \\ ${ }^{1}$ BioEnvironment, Health and Bioresources Team, Faculty of Sciences, University Ibn Zohr, Agadir, Morocco \\ ${ }^{2}$ Suprior Institute of Maritime Fishing, Agadir, Morocco \\ ${ }^{3}$ Laboratory of Ecology and Environment, Faculty of Sciences Semlalia, Marrakech, Morocco \\ ${ }^{4}$ Mauritanian Institute for Oceanographic Research and Fisheries, Nouadibou, Mauritania \\ ${ }^{5}$ Laboratory of Materials and Renewable Energy, Faculty of Sciences, Agadir, Morocco \\ ${ }^{6}$ Laboratory of "Aquatic Systems: Marin and continental field ", Faculty of Sciences, BP 28/S, Agadir, Morocco \\ ${ }^{7}$ Honorary Professor, University of Bordeaux, France \\ https://doi.org/10.35410/IJAEB.2021.5686
}

\begin{abstract}
The aim of this work was to investigate changes cytochromes P450 (CYP450) and some mixed function oxidases (MFOs) activities in Mytilus galloprovincialis and Pernaperna exposed in situ to pollution in Agadir marine bay (South of Morocco).

The main results showed a significant expression and induction of the analyzed activities in both mussels species. Thus, ethoxy-resorufin-O-deethylase (EROD) seems to be the most expressed MFO, while benzo[a]pyrene hydroxylase (BPH) would appear to be the most induced. 7methoxy-resorufin-O-demethylase (MROD), benzyloxy-resorufin O-debenzylase (BROD) and pentoxy-resorufin O-depentylase (PROD) activities are also expressed to a minor degree; however, they tend to be induced by the pollution in the polluted site (Anza).

The immunodetection of P4501A confirmed the results of the enzymatic measurements to which it seems to be complementary.

These results provide a first baseline of mixed-function oxidases (MFO) in Mytilus galloprovincialis and Pernaperna living in the Agadir bay and enable us to propose the activities of these enzymes, in particular BPH and EROD, as a biomarker of environmental pollution.
\end{abstract}

Keywords: Agadir marine bay - Biomarker - BPH - BROD - Cytochromes P450 - EROD Mixed function oxidases (MFO) - Morocco - Mytilus galloprovincialis - Pernaperna- Pollution PROD.

\section{INTRODUCTION}

Chemical pollution of marine ecosystems has led to the development of analytical techniques capable of detecting a wide spectrum of pollutants. Until the 1980s, monitoring of these ecosystems was based on chemical methods allowing the evaluation of the chemical contaminant's concentrations in compartments of the environment (water, sediment and organisms). However, such methods, essential for identifying contaminants, remain insufficient to provide information on the real impact of chemical pollution on the life of these ecosystems. 
Vol. 06, No. 06; 2021

ISSN: $2456-8643$

Indeed, there is a growing interest in the study and use of biological and particularly biochemical parameters, as indicators of environmental pollution, also known as biomarkers (Narbonne et al., 1991; Livingstone, 1993; Livingstone et al., 1997). Their use, at molecular or cellular level, have been proposed as sensitive early warning tools for biologic effect measurement in environmental quality assessment (Binelliet al., 2006). Such parameters are also used in a predictive way, allowing the application of strategies before environmental damage which can be irreversible (Paniagua-Michel and Olmos-Soto, 2016).

In the marine ecosystems, many biomarkers are currently used in international pollution monitoring programs in which mussels have been used as sentinel organisms, as they are capable of accumulate a variety of compounds at levels much higher than those found in their living environment (Soléet al., 1995; Livingstone 1996; Cajaravilleet al., 2000).Indeed, these organisms, of great ecological importance, wide geographical distribution and sessility in the wild preventing them from moving away from exposure to contaminants, filter feeders, bioaccumulate contaminants to a greater extent than the surrounding media (Cajaraville $e t$ al., 2000) and respond significantly to contaminant exposure. These responses, called biomarkers, resulting from a chain of biological effects and reflecting an integration of the biotic component of the contaminated ecological system, are now diagnostic, prognostic and early warning tools that offer the potential for specificity, sensitivity and application to a wide range of organisms and for discriminating ecosystem contamination over broad geographic areas.

The application of the biomarker approach was initiated in 1991 in the bay of Agadir (South of Morocco) well known for its fisheries resources and touristic beaches. Its use was carried out in the scope of biomonitoring of the health state of South Moroccan Atlantic coastal ecosystems. In previous studies, various biomarkers (Acetylcholinesterase, Catalase, Glutathione S-transferase activities and Malondialdehyde level) revealed a real disturbance of the physical and chemical characteristics of seawater and of marine organisms (Mytilus galloprovincialis and Perna perna) living in the sites receiving domestic and industrial wastewater of this ecosystem (Najimiet al., 1997, Moukrimet al., 1997; Kaayaet al., 1999).

This work aims to expand the panel of biochemical indicators of pollution tested to cytochromes P450 and some mixed-function oxidases (MFO) activities in Mytilus galloprovincialis and Pernaperna exposed in situ to pollution in Agadir marine bay (South of Morocco). Five types of monooxygenases were tested comparatively in Mytilus galloprovincialis and Pernaperna living in a control site (Cap Ghir) and a polluted site (Anza): three dependents on P4501A (EROD and BPH, P4501A1-dependent, MROD P4501A2-dependent) and two other dependents of P4502B1 (BROD and PROD). Tests for demonstrating P4501A1, by immunochemistry (Western blot), were also carried out, using a rat antibody directed against the P4501A1 protein which is the most prevalent in the different species.

Indeed, CYP450 and MFO system has been used as a biomarker of exposure to organic contaminants, since induction on their concentrations and activities reflects the PAHs concentrations in the aquatic environment (Petushoket al., 2002; Cravoet al., 2009). These enzymes exist in many forms, exhibiting substrate specificity (xenobiotic), and catalyse different reactions. This is the case for $\mathrm{P} 4501 \mathrm{~A}$ and $2 \mathrm{~B}$, which are induced respectively by plane xenobiotics (such as PAHs and plane PCBs) and/or globular (such as non-plane PCBs). Furthermore, the use of P4501A has been proposed as a biomarker (Payne, 1976; Monod et al., 1988; Vindimianet al., 1989; Burgeotet al, 1996; Burgeot\&Galgani, 1998). MFO activities, such 
as Acryl Hydrocarbon Hydroxylase (AHH), EthoxyRorufin O-Deethylase (EROD), EthoxyCoumarin O-Deethylase (ECOD), MethoxyRorufin O-Deethylase (MROD) and Benzo (a) Pyrene Hydroxylase (BPH) have also been used to measure the induction of P450 1A (Barnett et al. 1993). In addition, the immunochemical detection of $\mathrm{P} 450$ 1A has been recommended to complete and refine the induction responses obtained (Stegman et al., 1987; Goskoyr\&Forlin, 1992; Goksoyr, 1993).

EROD activity appears to be the most sensitive and widely used biomarker of aquatic pollution in many international programs (Hodson et al., 1991; Goksoyr\&Forlin, 1992; Namour, 1992; Burgeot\&Galgani, 1998).

As part of our study, we tested, on a preliminary basis, five types of monooxygenases in the two species in Cap Ghir and Anza: three P4501A-dependents activities (EROD and BPH, P4501A1dependent, MROD P4501A2-dependent) and two other P4502B1-dependents activities (BROD and PROD). Tests for demonstrating P4501A1, by immunochemistry (Western blot), were also performed, using a rat antibody directed against the most common P4501A1 protein in the different species.

\section{MATERIAL AND METHODS}

\section{Sampling sites}

The study was conducted on adult mussels: Mytilus galloprovincialis and Pernaperna (40 to 60 $\mathrm{mm}$ ) collected in two types of sites representative of the Agadir bay: i) a reference site, Cap Ghir, located far from any human activity, and ii) a polluted site (Anza) that receives untreated industrial and domestic wastewater from the Anza zone (Figure 1).

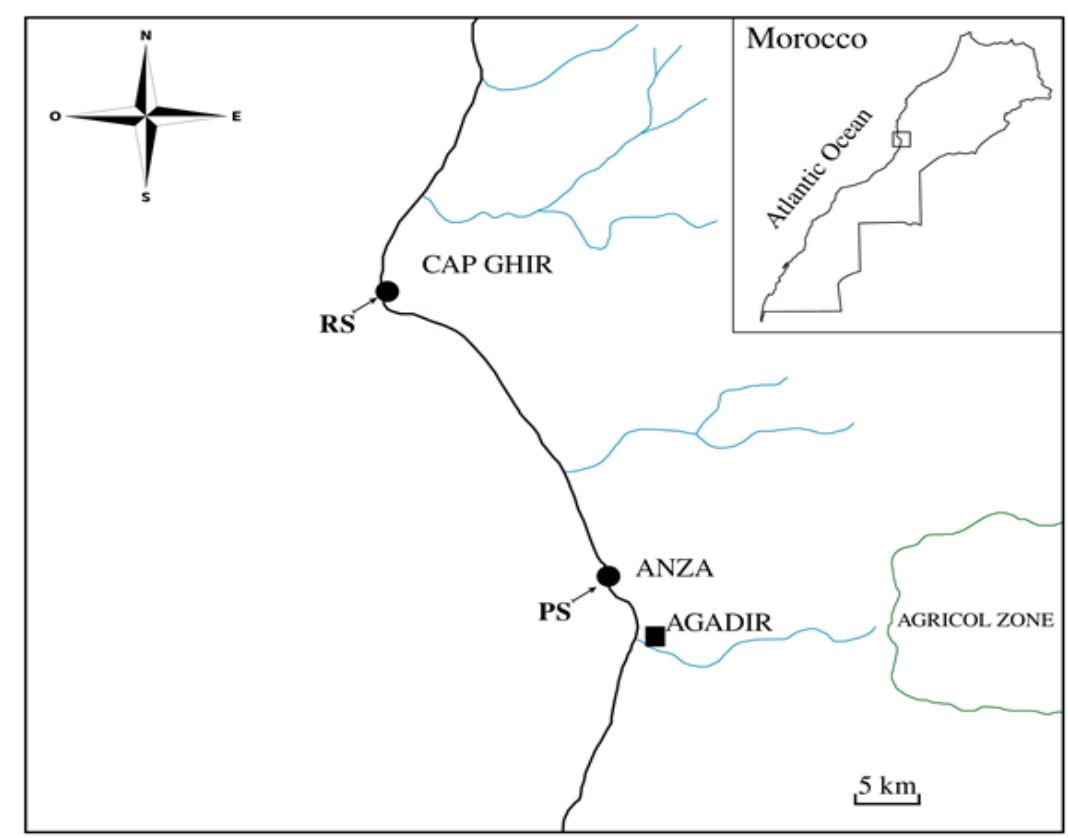

Figure 1: Map of sampling sites in Agadir bay(RS: Reference site and PS: Polluted site)

\section{Preparation of microsomes}


MFO activities analysis was performed on microsomes prepared from the digestive gland (Hepatopancreas) of mussels (Mytilus galloprovincialis and Perna perna). The choice of this organ was driven by its crucial role in the metabolism of xenobiotics.

After dissection of the animals, their digestive glands were removed and homogenized with Potter in phosphate buffer (100 mM pH 7.4). A pool of digestive glands from male and female animals is used for each sample in order to minimize sex-related variations (Michel, 1993).

After preparation of the post-mitochondrial fraction (S9), the supernatant was centrifuged at $105000 \mathrm{~g}$ for 1 hour. The pellet, corresponding to the microsomes, was collected in phosphate buffer (100 mM pH 7.4 containing $1 \mathrm{mM}$ EDTA and $20 \%$ glycerol) and stored in liquid nitrogen until the time of the assay. All operations were carried out at $4{ }^{\circ} \mathrm{C}$.

\section{Measurement of $\mathrm{BPH}$ activity}

The method used was that of Dehnenet al. (1973) adapted to mussels by Michel et al. (1994).

The reaction medium contains $0.75 \mathrm{mg}$ of microsomal proteins, $0.74 \mathrm{mM}$ of NADPH and $2 \mathrm{mg}$ of bovine albumin in $50 \mathrm{mM}$ Tris- $\mathrm{HCl}$ buffer, $\mathrm{pH}$ 7.4.

The reaction was initiated by the addition of benzo (a) pyrene (70 $\mu \mathrm{M}$ in methanol/acetone (v/v), then stopped after 10 minutes of incubation at $25^{\circ} \mathrm{C}$ with $100 \mu \mathrm{l}$ of a mixture of $10 \%$ Triton-X100/Triethylamine (v/v).

Centrifugation for $10 \mathrm{~min}$ at $3000 \mathrm{~g}$ could sometimes be used to clarify the incubate on which was measured the difference in fluorescence emitted in the medium, between $515 \mathrm{~nm}$ and 460 $\mathrm{nm}$, as an emission wavelength and at $435 \mathrm{~nm}$ as an excitation wavelength.

A range of 3 hydroxy-benzo (a) pyrene allowed to calculate the equivalent amount of $3 \mathrm{OH}-\mathrm{BaP}$ transformed per unit of time.

In the assay, fluorescence was measured using a spectrofluorometer (Shimadzu RF-540).

The BPH activity was expressed in picomoles of 3-hydroxybenzo(a)pyrene per mg of microsomal protein per minute ( $\mathrm{pmol} / \mathrm{mg}$ microsomal proteins $/ \mathrm{min}$ ).

\section{Measurement of EROD, MROD, BROD and PROD activities}

The protocol used for the assay of enzymatic activities mentioned above was adapted from the method ofBurke \& Mayer (1974) which allows the fluorometric measurement of resorufin, the product of the deethylation reaction of a substrate which differs according to the enzyme: 7 ethoxyresorufin for EROD, 7-methoxyresorufin for MROD, 7-benzooxyresorufin for BROD and 7-pentoxyresorufin.

The reaction medium contains $0.5 \mathrm{mg}$ of microsomal proteins diluted with phosphate buffer (50 $\mathrm{mM}, 5 \mathrm{mM} \mathrm{MgCl} 2$ at $\mathrm{pH} 7.4), 1.5 \mu \mathrm{M}$ of substrate dissolved in dimethylformamide.

After a $5 \mathrm{~min}$ pre-incubation at $25^{\circ} \mathrm{C}$, the reaction was initiated by the addition of the $1 \mathrm{mM}$ NADPH cofactor. The reaction is then stopped with trichloroacetic acid (5\%).

After centrifugation to remove the incubate, measurement of fluorescence, due to resorufin at the excitation and emission wavelengths of $530 \mathrm{~nm}$ and $585 \mathrm{~nm}$, respectively, is performed on the supernatant. The amount of product formed per unit of time is calculated from a standard range of resorufin.

In all assays, fluorescence was measured using a spectrofluorometer (Shimadzu RF-540).

The EROD, MROD, PROD and BROD activities were expressed in picomoles of resorufin per $\mathrm{mg}$ of microsomal proteins per minute ( $\mathrm{pmol} / \mathrm{mg}$ microsomal proteins/min). 
Vol. 06, No. 06; 2021

ISSN: $2456-8643$

The method of Lowry et al. (1951) was used for the quantitative determination of microsomal proteins using bovine serum albumin as the standard.

\section{Immunodetection of P450 1A by Western Blot}

This experimental protocol consists of three steps: electrophoresis allowing the separation of microsomal proteins according to their molecular weight on a polyacrylamide gel, electrotransfer to a membrane and immunodetection using an anti-P4501A antibody.

Electrophoresis of microsomal proteins was carried out under denaturing conditions on $10 \%$ polyacrylamide gel (SDS PAGE) (Laemmli, 1976). The microsomal proteins deposited in the gel wells migrate in Tris buffer ( $25 \mathrm{mM}$ Tris base, $0.75 \mathrm{mM}$ Glycine, $0.1 \%$ SDS, ) for 2 hours at constant amperage $(20 \mathrm{~mA})$ relative to proteins of known molecular weight.

After removing the gel from the mold, the proteins were transferred to a Polyvinylidene difluoride (PVDF-Millipore) membrane, in $25 \mathrm{mM}$ Tris base buffer, $192 \mathrm{mM}$ glycine, $15 \%$ methanol.

After removing the gel from the mold, the proteins were transferred to a Polyvinylidene difluoride (PVDF-Millipore) membrane, in $25 \mathrm{mM}$ Tris base buffer, $192 \mathrm{mM}$ glycine, $15 \%$ methanol and 0.1\% SDS (Towbinet al., 1979).

The immunoregulation, inspired by the method of Carrièreet al. (1992), was carried out after protein saturation of the free sites of the membrane using a Tris base buffer $1 \mathrm{M} \mathrm{NaCl} 3 \mathrm{M}$, bovine albumin 3\%, pH 7.4 (Tris Base Salin or TBS).

The detection of the P4501A immobilized on the membrane was performed after incubation for 1 hour with a primary polyclonal anti-rat P4501A antibody (diluted in TBS). After rinsing with TBS-Tween 80 at $0.1 \%$ and washing the membrane with TBS, a second incubation for 1 hour, with a secondary anti-goat IgG antibody coupled to peroxidase (diluted in TBS-BSA 1\%) was carried out. The visualization was performed out using a solution of $3.3^{\prime}$ diaminobenzidine (DAB) (15 mg DAB / 1001 of dimethyl sulfoxide diluted in 1\% TBS-BSA). The addition of 45 $\mu l$ of hydrogen peroxide allowed the visualization of proteins labelled with anti-P4501A antibodies on the membrane.

The revelation of P4501A in the two species of mussels was performed by comparison with a microsomal sample of rat liver induced by $\beta$ Naphthoflavone. This compound is a specific inducer of P4501A (Goksoyr\&Förlin, 1992).

\section{Statistical analysis}

The comparison between the means was carried out by the "t" test using Statistica Software (Release 4.5A Statsoft Inc. Ed. 1993).

\section{RESULTS AND DISCUSSION}

The comparison of the expression of the EROD, BPH, MROD, BROD and PROD activities between each other shows significantly that microsomal EROD activity is better expressed in the digestive gland of Mytilus galloprovincialis and Pernaperna than other activities. This observation is recorded for both control and polluted mussels (Figure 2). 

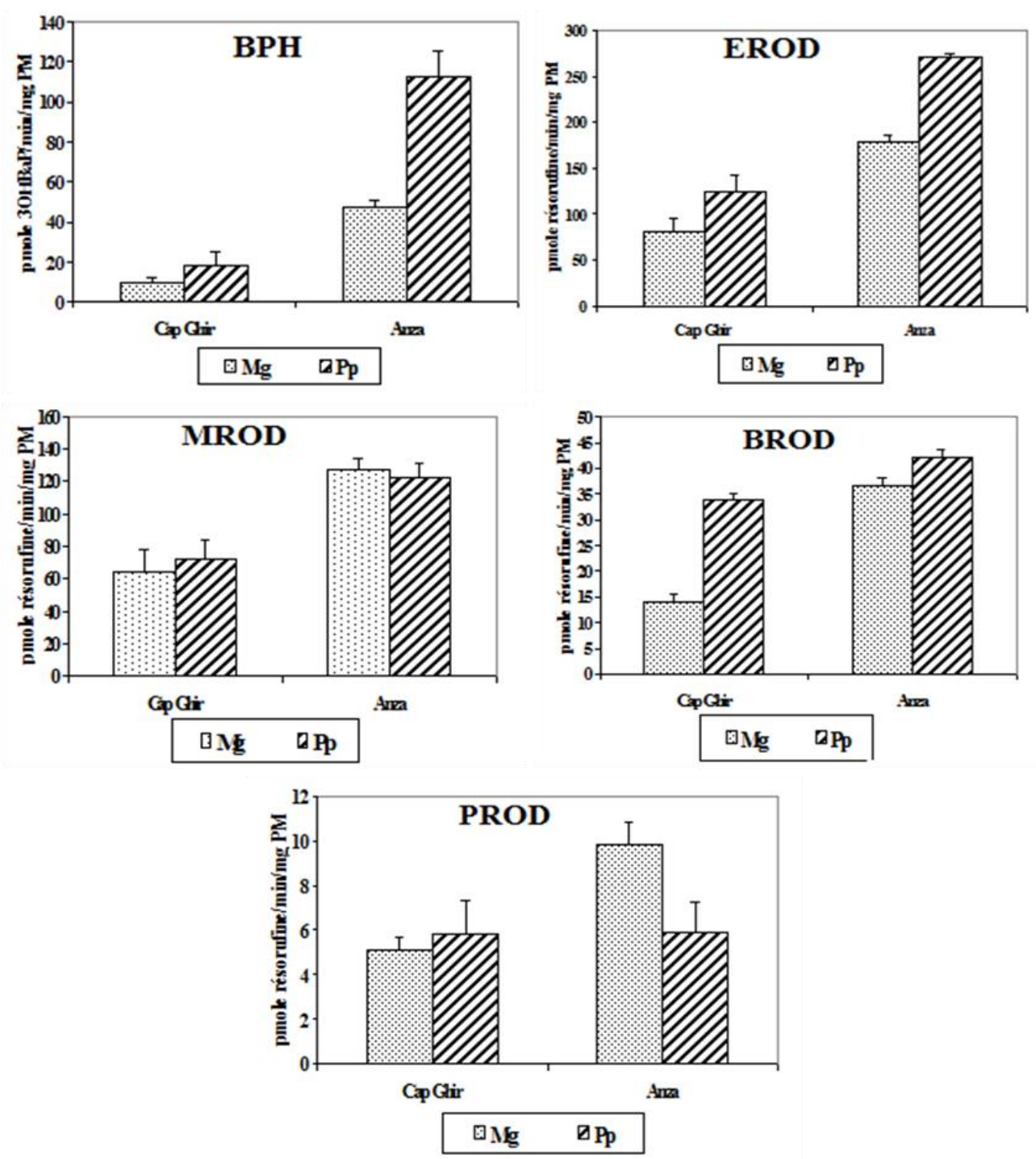

Figure 2: BPH, EROD, MROD, BROD and PROD activities in Mytilus galloprovincialis (Mg) and Pernaperna $(\mathrm{Pp})$ in the Cap Ghir and Anza sites; Values represent the mean $(\mathrm{n}=6) \pm$ SED

BPH, MROD and BROD activities are expressed in a moderate degree, whereas PROD activity is weakly expressed. These results reflect the good expression of EROD, as an MFO of the P4501A family, compared to other types of activities of the same family or another one of P450 family. The difference in expression between MFOs is known for many isoforms and in different aquatic species (Stegman et al., 1987; Monod et al., 1988; Stegman \& Hahn, 1994).

The examination of these activities according to the species shows that, irrespective of the site, BPH, EROD (except for Anza) and BROD activities are significantly higher in Pernaperna than in Mytilus galloprovincialis. However, no significant difference was recorded for the MROD and PROD activities. This kind of specific difference is known for monooxygenases that can vary widely between species (Andersson \&Forlin, 1992). Indeed, difference of levels of microsomal CYP content was described in MytilusedulisandMytilusgalloprovincialis(Livingstoneet al., 1989) 
Vol. 06, No. 06; 2021

ISSN: $2456-8643$

and in freshwater gastropod mollusks, Potamopyrgusantipodarumand Valvatapiscinalis (Gagnaireet al., 2010).

In fact, notable differences between marine species have been reported both for the baseline levels of P4501A, for dependent enzymatic activities and for the induction of these activities by certain pollutants (Goksoyr, 1995; Stien, 1998).

The comparison of the BPH, EROD, MROD, BROD and PROD activities according to the site shows that the highest values are recorded in the animals of the polluted site. Such variations would certainly be related to the pollution status of this plant which receives domestic and industrial wastewater from the city of Anza. This pollution effect is best illustrated by expressing it through the induction factor of the measured MFOs. This factor was calculated as the ratio of the MFO activities between those of the polluted site and those of the reference site (Figure 3).

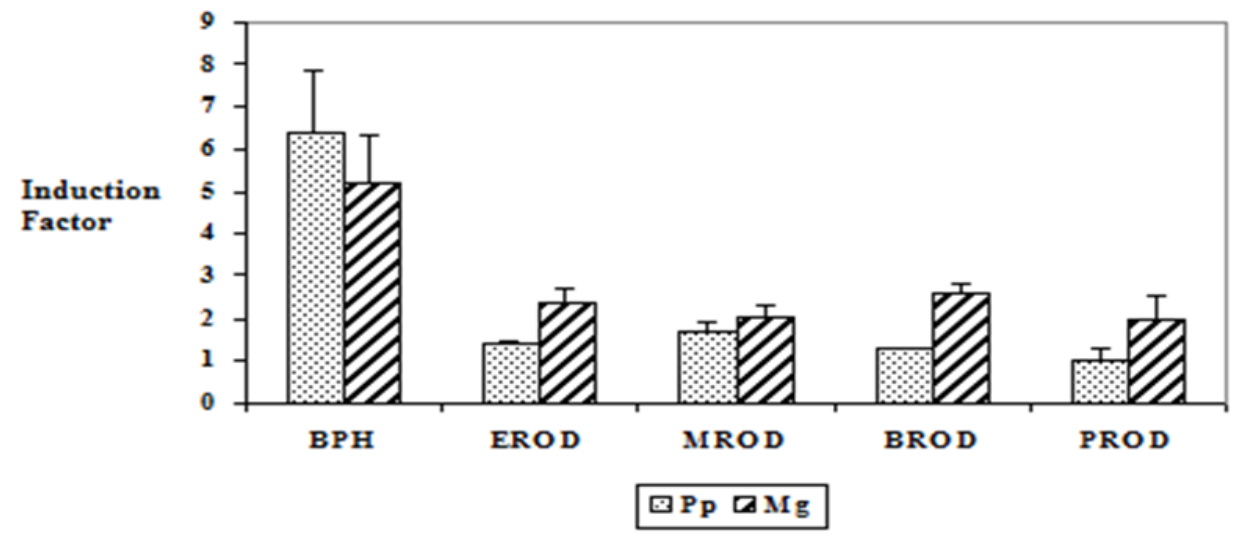

Figure 3: Induction factors of BPH, EROD, MROD, BROD and PROD activities by pollution of the Anza site in Mytilus galloprovincialis and Pernaperna; Values represent the mean $(n=6) \pm$ SED

The induction of MFO activities by Anza's domestic and industrial wastewater depends on the enzyme measured. Indeed, among the five MFOs measured and whatever the species, the BPH activity seems to be significantly the most induced. On the other hand, no significant difference related to the mussel species was recorded. This result could explain the fact that EROD is more widely used as a pollution biomarker in fish (Burgeot et al., 1996; Burgeot\&Galgani, 1998), while BPH is under development in mussels (Michel et al., 1993; Burgeot\&Galgani, 1998). The induction of MFOs tested by pollution would certainly be linked to the presence of contaminants such as PAHs and PCBs in the polluted site (Anza). Indeed, according to Kaaya (2002), the Anza site is more contaminated with PAHs than the Cap Ghir site.

The correlation between PAH levels and induction of MFO activities has been described by various authors in many marine species whose works proposed MFO, and particularly EROD and BPH, as biomarkers of marine pollution (Burgeotet al. 1994; Michel et al., 1994; Fenetet al., 1996 and 1997; Burgeot\&Galgani 1998; Michel et al. 1998, Akchaet al. 2000; Amuthaet al., 2009; Lopes et al., 2012).

The results concerning the immunodetection of P450 1A, which was complementary to the study of MFO P450 1A activities, are presented in Figure 4. 


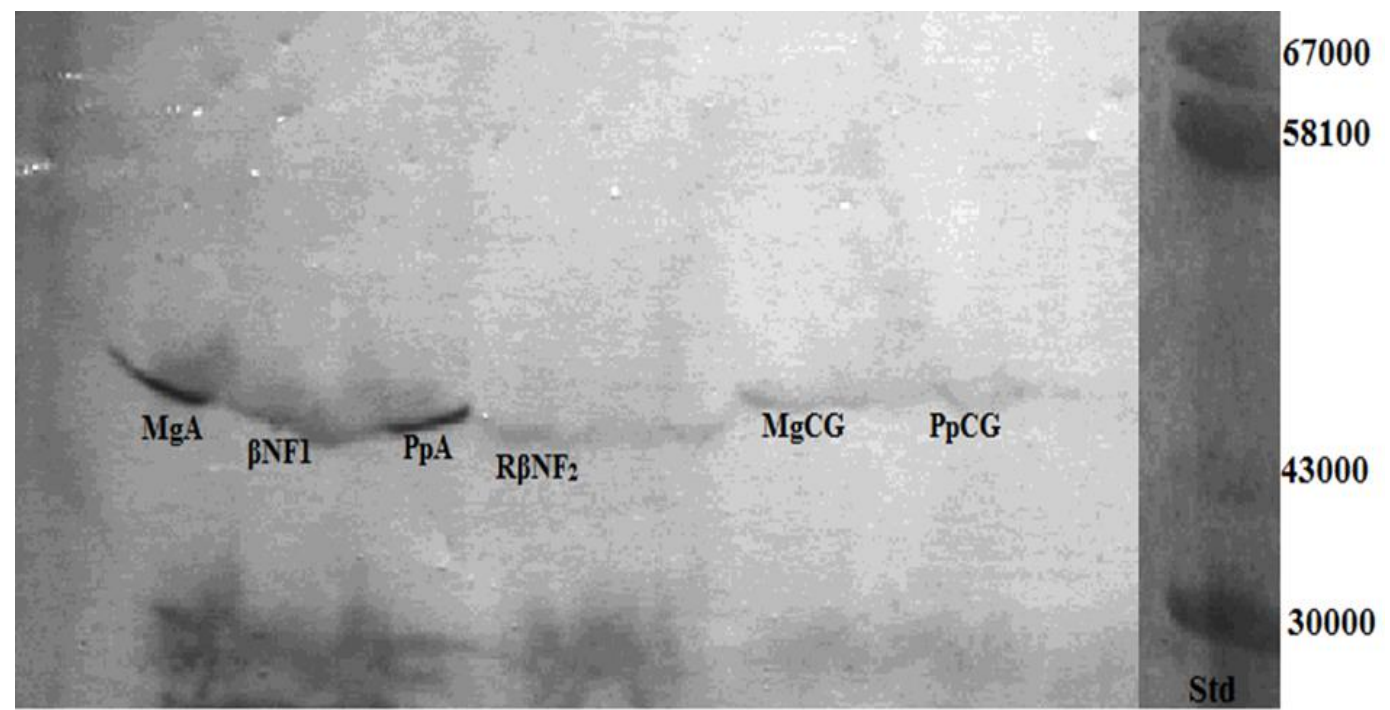

Figure 4: Immunodetection of $\mathrm{P} 4501 \mathrm{~A}$ on the hepatopancreas microsomes of Mytilus galloprovincialis $(\mathrm{Mg})$ and Pernaperna $(\mathrm{Pp})$ collected at Cap Ghir and Anza. $150 \mu \mathrm{g}$ of microsomal proteins per well, MgA: Hepatopancreas microsomes of Mg collected at Anza, RBNF1: Rat microsomes induced by undiluted $\beta$-naphthoflavone, PpA: Hepatopancreas microsomes of Pp collected at Anza, RBNF2: Rat microsomes induced by diluted $\beta$ naphthoflavone at 1/100, MgC: Mg hepatopancreas microsomes collected at Cape Ghir, PpC:

Pp hepatopancreas microsomes collected at Cap Ghir, Std: Molecular weight standards The comparison of their migration with that of the hepatic microsomal proteins of rats treated with $\beta$ Naphthoflavone ( $\beta B N F$ ) (specific inducer of P450 1A) reveals two major bands "MgA" and "PpA", which were strongly immunoreactive with the anti-rat P4501A antibody was strong. These bands correspond respectively to the microsomes of the digestive gland of Mytilus galloprovincialis and Pernaperna of the polluted site. These proteins have an apparent molecular weight, close to that of rat P4501A (bands R $\beta N F 1$ and 2), between 45,000 and 52,000 Da. Indeed, bands well detected for "MgA" and "PpA" and less detectable for "MgC" and "PpC" correspond respectively to the microsomes of Mytilus galloprovincialis and Pernaperna of the polluted and reference site.

The intense bands clearly demonstrate that P4501A is induced in the microsomes of mussels from the polluted site. These results should be correlated with those obtained by measuring the MFO P4501A-dependent activities: BPH, EROD and MROD and PAH content in the sediments. Our results also show that the anti- (rat hepatic P4501A) antibody is able to react with microsomal antigenic proteins of hepatopancreas, Mytilus galloprovincialis and Pernaperna. This could be explained by the similarities between P4501A from mussels and rats. This similarity of P4501A is known in many species (Goksoyr\&Forlin, 1992; Forlin\&Celander, 1993).

Similar results have been described following in situ studies in different fish species (Goskoyret al., 1991; Stegeman \& Hahn 1994; Fenet, 1997) and in Mytilus edulis and Mytilus galloprovincialis (Livingstone et al., 1995; Porte et al., 1995; Wootton et al., 1995). In addition, numerous studies have revealed the induction of other types of by Western blotting or immunodetection (Miranda et al., 1990; Goskoyret al., 1991; Stegeman et al., 1991). The revelation by western blot analysis of CYPIA-like protein in digestive gland microsomes of 
Vol. 06, No. 06; 2021

ISSN: $2456-8643$

Mytilus galloprovincialis was also described by Peters et al. (1998). Moreover, Porte et al. (1995) showed the recognition by anti-CYPIA fish antibodies of a partially purified P450 from Mytilus edulis.

Ours results provide evidence of the molecular presence, expression and induction by pollution of CYP1A gene in mussel, Mytilus galloprovincialis and Pernaperna. The same result was described after exposition of mussels to planar PAHs and PCBs (Livingstone 1991) and in the field (Wotton et al., 1995). On the other hand, Canova et al. (1998) have decribed a significant increase in CYPIA-like immunopositive proteins recorded in mussels exposed to B[a]P. Furthermore, several authors propose immunological determination as a biomarker and as a complement to catalytic tests, to solve the problem of loss and denaturation of P4501Adependent MFOs during sample storage (Forlinet al., 1985; Goksoyr, 1991; Forlin\&Celander, 1993; Kloepper-Sams\& Benton, 1994; Collier et al., 1995).

All of these results show that P4501A-dependent MFOs, validated as biomarkers via EROD, can also be measured by immunodetection. This type of study could provide a very useful complement to the determination of catalytic activities in the detection of responses induced by organic pollutants.

\section{CONCLUSION}

The results above highlighted the BPH, EROD, MROD, BROD and PROD activities in Mytilus galloprovincialis and Pernaperna collected in the bay of Agadir (South of Morocco). These activities are expressed and induced at different levels in these animals. Thus, EROD would be the most expressed MFO, while the BPH would seem to be the most induced.

MROD, BROD and PROD activities are also expressed to a lesser degree, however, they would seem to be induced by pollution in Anza.

The immunodetection of P4501A confirmed the results of the enzymatic measurements to which would appear to be complementary. These results are in favor of a study to validate the use of MFOs, in particular BPH and EROD, as a biomarker of environmental pollution.

\section{REFERENCES}

Akcha F., Izul C., Verrier P., Budzinski H., Burgeot T. and Narbonne J. F. (2000). Enzymatic biomarkers measurement and study of DNA adducts benzo(a)pyren contamination mussselsMytilus galloprovincialis. Aqua. Toxicol., 49: pp. 269-287.

Amutha C., G. Bupesh, R. Ramesh, P. Kavitha and P. Subramanian(2009). Cytochrome P450dependent Mixed Function Oxidases (MFO) System dynamics during the Poly Aromatic Hydrocarbon (PAH) metabolism in Green Mussel PernaViridis (Linnaeus, 1758). Environmental Bioindicators, 4:1, pp 97-116.

Anderson T. and Förlin L. (1992). Regulation of the cytochrome P450 enzyme system in fish. Aquat. Toxicol. 24, pp. 1-20.

Barnett A., Rattner, Mark J. Melancon, Thomas W. Custer, Roger L. Hothem, Kirke A. King, Leonard J. Lecaptain, James W. Spann, Bruce R. Woodin and John J. Stegeman (1993). Biomonitoring environmental contamination embryos: Induction of cytochrome p450 with pipping black-crowned night heron. Environmental Toxicology and Chemistry, VoI 12, pp 1719-1732. 
Vol. 06, No. 06; 2021

ISSN: $2456-8643$

Binelli A., F. Ricciardi, C. Riva and A. Provini (2006). New evidences for old biomarkers: effects of several xenobiotics on EROD and AChE activities in Zebra mussel (Dreissenapolymorpha). Chemosphere, 62(4): pp 510-519.

Burgeot T., Bocquéné G., Pingray G., Godefroy D., Legrand J., Dimeet J., Marco F., Vincent F., Henocque Y., OgerJeanneret and Galgani F. (1994). Monitoring biological effects of contamination in marine fish along Frensh coasts by measurment of ethoxyresorufinOdeethylase activity. Ecotoxicol. Environ. Saf., 29 : pp.131-147.

Burgeot T., Bocquéné G., Porte C., Dimmeet J., Santella R. M., Garcia de La Parra L. M., PfholLeszkowicz A., Raoux C. and Galgani F. (1996). Bioindicators of pollutant in the northwestern Mediterranean Sea. Mar. Ecol. Prog. Ser., 131 : pp.125-141.

Burgeot T. and Galgani F. (1998). Application de l'EROD chez les poissons marins dans un programme pluridisciplinaire de surveillance de la mer du nord. In :Utilisation de biomarqueurs pour la surveillance de la qualité de l'environnement, Lagdic L., Caquet Th., Amiard J.C. \&Ramade (Eds), Lavoisier, Tec \& Doc. pp. 33-56.

Burke M. D. and Mayer R. T. (1974). Ethoxyresorufin: direct fluorometric assay of microsomal O-dealkylation which is preferentially inducible by 3-methylcholanthrene. Drug. Metab. Disp., 2: pp. 583-588.

Canova, S., Degan, P., Peters, L. D., Livingstone, D. R., Voltan, R and Venier, P. (1998). Tissue dose, DNA adducts, oxidative DNA damage and CYP1A-immunopositive proteins in mussels exposed to waterbome benzo[a]pyrene. Mutat. Res., 399: PP 17-30.

Cajaraville M. P., Bebianno M. J., Blasco J., Porte C., Sarasquete C. and Viarengo A. (2000). The use of biomarkers to assess the impact of pollution in coastal environments of the Iberian Peninsula: a practical approach. Sci. Total Environ. 247: pp 295-311.

Collier T. K., Anulacion B., Stein J., Goksoyr A. and Varanasi U. (1995). A field evaluation of cytochrome P4501A as a biomarker of contaminant exposure in three species of flatfish. Environ. Toxicol. Chem., 14(1): pp. 143-152.

Cravo A., Lopes B., Serafim A., Company R., Barreira L., Gomes T. and Bebianno M. J. (2009). A multibiomarker approach in Mytilus galloprovincialis to assess environmental quality. Journal of Environmental Monitoring, 11, pp 1673-1686.

Carrière V., De Wazieres I., Courtois Y. A., Ceroux J. P. and Beaune P. H. (1992). Cytochrome p-450 induction and mutagenicity of 2-amino-anthracene (2 AA) in rat liver and gut. Mut. Res., $268:$ pp. 11-20.

Fenet H. (1997). Les biomarqueurs chez l'anguille européenne en cage: Application à la biosurveillance des eaux superficielles. Doctorat, Université de Montpellier I,151p + annexes.

Fenet H., Casellas C. and Bontoux J. (1996). Hepatic enzymatic activities of the European eel Anguilla anguilla as tool for biomonitoring freshwater streams: Laboratory and field caging studies. Wat. Sci. Tech., 33(6): pp. 321-329.

Forlin L., Anderson T., Bengtsson B., Hardig J. and Larson A. (1985). Effects of pulp plant effluents on hepatic xenobiotic biotransformation enzymes in fishes: laboratory and field studies. Mar. Environ. Res., 17: pp. 109-112.

Forlin L. and Celander M. (1993). Induction of cytochrome P40501A in teleosts : environmental monotoring in Swedish fresh, brackish and marine waters. Aquat. Toxicol., $26:$ pp. 41-56. 
Vol. 06, No. 06; 2021

ISSN: $2456-8643$

Gagnaire Béatrice, Olivier Geffard, Patrice Noury and Jeanne Garri (2010). In vivo indirect measurement of cytochrome p450-associated activities in freshwater gastropod molluscs. Environmental Toxicology, 25(6) : pp 545-53.

Goksøyr A. (1991). A semi-quantitative cytochrome P4501A ELISA: a simple method for studying the monooxygenase induction response in environmental monitoring and ecotoxicological testing of fish. Sci. Tot. Environ., 101: pp. 255-262.

Goksøyr A., Andersson T., Buhler D. R., Stegeman J. J., Williams D. E. and Förlin L. (1991). Immunochemical cross-reactivity of $\beta$-naphtoflavone-inducible cytochrome P-450 (P-4501A) in liver microsomes from different fish and rat. Fish. Physiol. Biochem., 9: pp.1-13.

Goksøyr A. (1993) Immunoassays for CYP450 1A1 induction in fish: New answers with western blotting, ELISA and immunohistochemistry. FAO/IOC/UNEP Training Workshop on Selected Techniques for monitoring Biological Effects of Pollutants in Marine organisms, Nice, France, 14-25 September 1992. Mediterranean Action Plan (MAP) Technical Reports Series, 7: pp.77-95.

Goksøyr A. (1995). Use of cytochrome P4501A (CYP1A) in fish as biomarker of aquatic pollution. Arch. Toxicol., 17: pp.80-95.

Goksøyr A. and Forlin L. (1992). The cytochrome P-450 system in fish aquatic toxicology and environmental monotoring. Aquat. Toxicol. 22: pp. 287-312.

Hodson P. V., Kloepper-Sams P. J., Munkittrrick K. R., Lockhart W. L., Metner D. A., Luxon P. L., Smith I. R., Gagnon M. M., Servos M. and Payne J. F. (1991). Protocols for measuring mixed function oxygenases of fish liver. Canadian Technical Report of Fisheries and Aquatic sciences, pp.: 18-29.

Kaaya A. (2002). Utilisation des moules Pernaperna et Mytilusgalloprovincialis comme bioindicateur de la pollution dans la baie d'Agadir : étude écophysiologique. Thèse de Doctorat d'Etat, Faculté des Sciences, Université Ibn Zohr, Agadir.

Kaaya A., S. Najimi, D. Ribera, J. F. Narbonne and A. Moukrim (1999). Characterization of Glutathione S-Transferases (GST) Activities in Pernaperna and Mytilus galloprovincialisUsed as a Biomarker of Pollution in the Agadir Marine Bay (South of Morocco). Bull. Environ. Contam. Toxicol. (1999) 62: pp 623-629.

Kloepper-Sams P. J. and Benton E. (1994). Exposure of fish to biologically treated bleachedkraft effluent. 2. Induction of hepatic cytochrome P4501A in mountain whitefish (Prosopiumwilliamsoni) and other species. Environ. Toxicol. Chem., 13(9): pp. 1469-1482.

Laemmli U. K (1970) Cleavage of structural proteins during the assembly of the head of the bacteriophage T4. Nature, 227: pp. 680-685.

Livingstone, D. R (1991). Organic xenobiotic metabolism in marine invertebrates. In: Advances in comparative and Environ. physiology, Gilles, D. R. (Ed), Springer Verlag, Berlin, pp 45185.

Livingstone D. R. (1993). Biotechnology and pollution monitorin: using of molecular biomarkers in the aquatic environment. J. Chem. Tech. Biotechnol., 5: pp.195-211.

Livingstone D. R. (1996) Cytochrome P450 in pollution monitoring. Use of cytochrome P4501A (CYP1A) as a biomarker of organic pollution in aquatic and other organisms. In: Richardson M (ed) Environmental xenobiotics. Taylor \& Francis, London, pp 143-160.

Livingstone D. R., Kirchin M. A. and Wisean A. (1989). Cytochrome P-450 and oxidative metabolism in molluscs. Xenabiotica 19: pp 1041-1962. 
Livingstone D. R, Lemaire P., Mattews A., Peters L. D., Porte C., Fitzpatrick P. J., Förlin L., Nasci C., Fossato V., Wootton N. and Goldfarb P. (1995). Assessment of the impact of organic pollutants on goby (Zosterisessorophiocephalus) and mussel (Mytilus galloprovincialis) from the Venice lagoon, Italy: biochemical studies. Mar. Env. Res., 39: pp. 235-240.

Livingstone D. R., Nasci C., Sole M., Da Ros L., O'Hara S. C. M., Peters L. D., Fossato V., Wootton A. N. and Goldfarb P. S. (1997). Apparent induction of a cytochrome P450 with immunochemical similarities to CYP1A in digestive gland of the common mussel (Mytilus galloprovincialis L.) with exposure to 2,2',3,4,4',5'-hexachlorobiphenyl and Aroclor 1254. Aquat. Toxicol.;38: pp 205-224.

Lopes B., A. M. Ferreira and M. J. Bebianno (2012). Responses of CYP450 dependent system to aliphatic and aromatic hydrocarbons body burden in transplanted mussels from South coast of Portugal. Ecotoxicology, 21: pp 730-749.

Lowry O. H., Roseborough N. J., Farrand A. L. and Randall R. J. (1951). Protein measurement with the Folin phenol reagent. J. Biol. Chem. 193: pp. 265-275.

Michel X. (1993). Contribution à l'étude des interactions entre les contaminants chimiques organiques et les organismes marins : Bases moléculaires et application à la biosurveillance de l'environnement côtier. Thèse de Doctorat. Université de Bordeaux I, 234p.

Michel X., Salaün J. P., Galgani F. and Narbonne J. F. (1994). Benzo(a)pyrene hydroxylase activity in the marine mussel, Mytilus galloprovincialis: a potent marker of contamination by polycyclic aromatic hydrocarbons. Mar. Environ. Res., 38 : pp.257-273.

Michel X., Suteau P., Robertson L. W. and Narbonne J. F. (1993). Effects of benzo(a)pyrene, 3,3', 4,4'-tetrachlorobiphenyl and 2,2', 4,4', 5,5'-hexachlorobiphenyl on the xenobioticmetabolizing enzymes in the mussel, (Mytilus galloprovinialis). Aquat. Toxicol., 27: pp.335344.

Miranda C. L., Wang J. L., Henderson M. C. and Buhler D. R. (1990). Immunological characterization of constitutive isozymes of cytochrome $\mathrm{P} 450$ from rainbow trout. Evidence for homology with phenobarbital-induced rat P-450S. Biochim. Biophys. Acta., 1037: pp. 155160.

Monod G., Devaux A. and Rivière J. L. (1988). Effects of chemical pollution on the activities of hepatic xenobiotic metabolizing enzymes in fish from the river Rhône. Sc. Total Environ., 73: pp. 189-201.

Moukrim A., Bouhaimi A., Lagbouri A. and Zekhnini A. (1997) Health state of Agadir bay ecosystems evaluated by biomarkers of pollution. Proceedings of International Symposium on Environmental Pollution and Impact Assessment, 9- 11 October 1996, Mohammedia, Morocco, 325-337.

Najimi S., Bouhaimi A., Daubèze M., Zekhnini A., Pellerin J., Narbonne J. F. and Moukrim A. (1997). Use of Acetylcholinesterase in Pernaperna and Mytilus galloprovincialis as a biomarker of pollution in Agadir Marine Bay (South of Morocco). Bull. Environ. Contam. Toxicol.; 58(6): pp 901-908.

Namour P. (1992). Les monooxygénases de poissons, un outil pour la caractérisation des pollutions chroniques. Etudes du CEMAGREF, série Ressource en eau, $n^{\circ}$ 6, 232p.

Narbonne J. F., Garrigues P., Ribera D., Raoux C., Mathieu A., Lemaire P., Salaün J. P. and Lafaurie M. (1991). Mixed-function oxygenase enzymes as tools for pollution monitoring: 
Vol. 06, No. 06; 2021

ISSN: $2456-8643$

field studies on the French coast of the mediterranean sea. Comp. Biochem. Physiol., 100C (1/2): pp. 37-42.

Paniagua-Michel J. and Olmos-Soto J. (2016). Modern Approaches into Biochemical and Molecular Biomarkers: Key Roles in Environmental Biotechnology. Journal of Biotechnology \& Biomaterials, Vol 6: Issue 1, pp 1-8.

Payne J. F. (1976). Field evaluation of benzo(a)pyrene hydroxylase induction as a monitor for marine petroleum pollution. Science, 191: pp. 945-946.

Pereira, C. D. S., Martin-Diaz, M. L., Catharino, M. G. M., Cesar, A., Choueri, R. B., Taniguchi, S., Abessa, D. M. S., Bicego, M. C., Vasconcellos, M. B. A., Bainy, A. C. D., Sousa, E. C. P. M. and Del Valls, T. A. (2012). Chronic contamination assessment integrating biomarkers' responses in transplanted mussels-A seasonal monitoring. Environ. Toxicol. 27, pp 257-267.

Peters, L. D., Nasci, C. and Livingstone, D. R. (1998). Variation in levels of cytochrome P4501A, 2B, 2E, 3A and 4A-immunopositive proteins in digestive gland of indigenous and transplanted mussel Mytilus galloprovincialis in Venice Lagoon, Italy. Mar. Environ. Res., 46: $p p$ 295-299.

Petushok N., Gabryelak T., Palecz D., Zavodnik L., SzollosiVarga I. and Deér K.A. (2002). Comparative study of the xenobiotic metabolising system in the digestive gland of the bivalve molluscs in different aquatic ecosystems and in aquaria experiments. Aquat. Toxicol. 61, pp 65-72.

Porte, C., Lemaire, P., Peters, L. D. and Livingstone, D. R. (1995). Partial purification and properties of cytochrome P450 from digestive gland microsomes of the common mussel Mytilus sp. Mar. Environ. Res., 39: pp 21-26.

Stegman J. J. and Kloepper-Sams P. J. (1987) Cytochrome P450 isozymes and monooxygenase activity in marine animals. Environ. Health Persp., 71: pp. 37-44.

Stegeman J.J., Smolowitz R. M. and Hahn M. (1991) Immunohistochemical localization of environmentally induced cytochrome P450 1A1 in multiple organs of the marine teleost Stenotomuschrysops (Scup). Toxicol. Appl. Pharmacol. 110, pp.486-504.

Stegeman J. J. and Hahn M. E. (1994). Chapter 3: Biochemistry and molecular biology of monooxygenases: current perspectives on forms, functions and regulation of cytochrome P450 in aquatic species. In: Aquatic Toxicology: Molecular, Biochemical and Cellular Perspectives, Ostrander G.K. \&Malins D. (Eds), Boca Raton, (Lewis Publishers), pp 87-206.

Solé M., Porte C., Albaige's J. (1995) Seasonal variation in the mixed function oxygenase system and antioxidant enzymes of the mussel Mytilus galloprovincialis. Environ Toxicol Chem 14(1): pp 157-164.

Stien X. (1998). Validation de biomarqueurs d'exposition pour la surveillance de l'environnement marin et clonage du cytochrome P450A chez Dicentrarchuslabrax. Doctorat de l'Université de la Méditerranée, Observatoire des Sciences de l'Univers, Centre d'Océanologie de Marseille, 210p.

Towbin H., Staehelin T. and Gordon J. (1979). Electrophoretic transfer of proteins from polyacrylamide gels to nitrocellulose sheets: procedure and some applications. Proc. Natl. Acad. Sci. USA, 76: pp. 4350-4054.

VarapornCholumpai, Malin C. Celander and PraparsiriKanchanopas-Barnette (2015). Accumulation and clearance of PAHs and CYP1A levels in farmed green Mussels 
International Journal of Agriculture, Environment and Bioresearch

Vol. 06, No. 06; 2021

ISSN: $2456-8643$

(Pernaviridis L.) from a coastal industrial area in Thailand. Environment Asia, 8(2): pp 109117.

Vindimian E. and Garric J. (1989). Freshwater fish cytochrome P450 dependent enzymatic activities: a chemical pollution indicator. Ecotoxicol. Environ. Saf., 18: pp. 277-285.

Wootton AN., Herring C., Andy Spry J., Wiseman A., Linvingstone DR. \& Goldfarb PS. (1995). Evidence for existance of cytochrome P450 gene families (CYP1A, 3A, 4A, 11A) and modulation of gene expression (CYP1A) in the mussel Mytilus sp. Mar. Environ. Res., 39: pp. 21-26. 